\title{
Faktor-Faktor Yang Mempengaruhi Kinerja Karyawan RSUD S.K. Lerik Kota Kupang
}

\author{
John EHJ FoEh ${ }^{1,{ }^{\star}}$, Kardinah Indriana Meutia ${ }^{1}$, Rudy Basuki ${ }^{2}$ \\ ${ }^{1}$ Fakultas Ekonomi dan Bisnis; Universitas Bhayangkara Jakarta Raya; Jln Perjuangan 081, \\ Marga Mulya, Bekasi, 02188955882/022188955871; e-mail: johnfoeh@gmail.com, \\ kardinah.indriana@dsn.ubharajaya.ac.id \\ ${ }^{2}$ Fakultas Manajemen; Universitas Widya Mandira; Jalan A. Yani No. 50-52 Merdeka, \\ Kupang, NTT, 0380833395/0380831194; e-mail: rudybasuki49@gmail.com

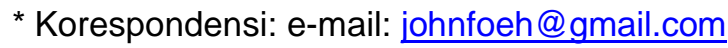

Submitted: 09/08/2021; Revised: 09/08/2021; Accepted: 02/09/2021; Published: 30/09/2021

\begin{abstract}
The purpose of the research is to know: (1). Leadership profile, discipline, training and employee performance at RSUD S.K. Lerik Kupang City (2). The influence of leadership on the performance of RSUD S.K. Lerik Kupang City (3). The influence of employee discipline on the performance of RSUD S.K. Lerik Kupang City (4). Effect of training on the performance of RSUD S.K. Lerik Kupang City. The study was conducted on all members of the employees at RSUD S.K. Lerik Kupang City. The sampling technique used the census method, thus the number of samples was 232 peoples. The data collected were analyzed descriptively based on the results of processed data using the method of Structural Equation Model. The results of the descriptive analysis describe the achievement of the performance variable indicators are $78.43 \%$ (good category); achievement indicator variable leadership is $79.27 \%$ (good category); achievement indicators for discipline reached a score of $80.47 \%$ (good category); and the achievement of the training variable indicator is $77.80 \%$ (good category). Based on the SEM analysis with AMOS, the results showed that the leadership and training variables had a significant effect on the performance of the employees of RSUD S.K. Lerik Kota Kupang with $C R$ values of 3,589 and 10,974 respectively. The same analysis shows that the discipline variable has no effect on the performance of the employees of RSUD S.K. Kupang City Lerik. This can be seen from the CR value of only 0.662 .
\end{abstract}

Keywords: Employee Performance, Leadership, Discipline, Training

\begin{abstract}
Abstrak
Tujuan dari penelitian untuk mengetahui: (1). Profil kepemimpinan, disiplin, pelatihan dan kinerja pegawai di RSUD S.K. Lerik Kota Kupang (2). Pengaruh kepemimpinan terhadap kinerja RSUD S.K. Lerik Kota Kupang (3). Pengaruh disiplin pegawai terhadap kinerja RSUD S.K. Lerik Kota Kupang (4). Pengaruh pelatihan terhadap kinerja RSUD S.K. Kota Lerik Kupang. Penelitian dilakukan pada seluruh pegawai di RSUD S.K. Kota Lerik Kupang. Teknik pengambilan sampel menggunakan metode sensus, sehingga jumlah sampel adalah 232 orang. Data yang terkumpul dianalisis secara deskriptif berdasarkan hasil pengolahan data menggunakan metode Structural Equation Model. Hasil analisis deskriptif menggambarkan ketercapaian indikator variabel kinerja sebesar $78,43 \%$ (kategori baik); indikator pencapaian variabel kepemimpinan adalah $79,27 \%$ (kategori baik); indikator pencapaian disiplin mencapai skor $80,47 \%$ (kategori baik) dan ketercapaian indikator variabel pelatihan sebesar $77,80 \%$ (kategori baik). Berdasarkan analisis SEM dengan AMOS diperoleh hasil bahwa variabel kepemimpinan dan pelatihan berpengaruh signifikan terhadap kinerja pegawai RSUD S.K. Lerik Kota Kupang dengan nilai CR masing-masing sebesar 3.589 dan 10.974. Analisis yang sama menunjukkan bahwa variabel disiplin tidak berpengaruh terhadap kinerja pegawai RSUD S.K. Lerik Kota Kupang. Hal ini terlihat dari nilai CR yang hanya sebesar 0,662.
\end{abstract}


Kata kunci: Kinerja Karyawan, Kepemimpinan, Disiplin, Pelatihan

\section{Pendahuluan}

Rumah Sakit Umum Daerah (RSUD) S.K. Lerik di kota Kupang sebagai Organisasi Perangkat Daerah (OPD) dalam melaksanakan tugas pokok dan fungsinya tentunya diperhadapkan dengan berbagai isu dan permasalahan strategis terutama yang menyangkut kualitas pelayanan kesehatan yang belum optimal, jumlah dokter dan tenaga keperawatan atau profesional lainnya, manajemen rumah sakit yang kurang responsif terhadap permasalahan yang dihadapi akibat sistem yang kurang fleksibel tenaga sumber daya manusia (SDM) yang melayani termasuk penyelenggaraan birokarasi yang kaku. Hal lain yang masih harus diperbaiki tentunya berhubungan dengan tingkat kebutuhan masyarakat dan harapan pasien yang terus berkembang dan bervariasi dari waktu ke waktu.

Hasil kajian terhadap data sekunder dan konfirmasi kepada pihak manajemen diketahui bahwa RSUD yang didirikan pada tahun 2010 ini masih belum mencapai kinerja operasional termasuk kinerja SDM yang memadai. Dari data juga diketahui bahwa RSUD ini telah terakretasi tahun 2012 dan juga telah memperoleh sertifikasi ISO 9001-2015. Namun demikian capaian kinerja organisasi belumlah memadai sebagaimana yang telah ditargetkan. Sebagai contoh, capaian kinerja dapat dilihat pada Tabel 1 berikut ini.

Tabel 1. Capaian Kinerja RSUD S.K. Lerik Tahun 2017

\begin{tabular}{|c|c|c|c|c|}
\hline No. & Uraian & Target & \multicolumn{2}{|c|}{ Realisasi } \\
\hline 1. & $\begin{array}{l}\text { Pemakaian tempat tidur (Bed Turn } \\
\text { Over/ BTO) }\end{array}$ & 4431 buah/ unit & 1732 buah/unit & $39,09 \%$ \\
\hline 2. & Kelengkapan sarana gedung/ fisik & 120 ruangan & 52 ruangan & $43,33 \%$ \\
\hline 3. & Pengadaan mobil ambulance & 3 unit & - & $0 \%$ \\
\hline 4. & $\begin{array}{l}\text { Pemeliharaan rutin/ berkala } \\
\text { ambulance }\end{array}$ & 6 kali & 2 kali & $33,33 \%$ \\
\hline 5. & $\begin{array}{l}\text { Pemeliharaan rutin/ } \\
\text { kesehatan rumah sakit }\end{array}$ & 6 kali & 3 kali & $50 \%$ \\
\hline 6. & $\begin{array}{l}\text { Pelatihan oleh Kementerian, } \\
\text { Pemprov, dan IDI }\end{array}$ & 12 kali & 9 kali & $75 \%$ \\
\hline 7. & $\begin{array}{l}\text { Rata-rata lama pasien dirawat } \\
\text { (Average Length of Stay }=\text { ALOS) }\end{array}$ & 3 hari & 2 hari & $66,67 \%$ \\
\hline
\end{tabular}

Sumber: Laporan Kinerja (LAKIP) (2018)

Sesuai data pada Tabel 1, jumlah keikutsertaan dalam pelatihan yang diadakan oleh

Pemerintah Provinsi, Kementerian Kesehatan dan Ikatan Dokter Indonesia belum sesuai target dikarenakan keterbatasan dana atau hal teknis lainnya seperti keterlambatan informasi pelatihan dari pihak penyelenggara. Pengadaan mobil ambulance pada tahun 2016 mengalami kendala, dan tidak ada realisasi. Hal ini dikarenakan ada kesalahan dalam membuat spesifikasi kendaraan pada dokumen anggaran sehingga pengadaan tersebut dibatalkan. Selanjutnya, Average Length Of Stay (ALOS) adalah rata-rata lama perawatan seorang pasien di rumah sakit, memberikan gambaran tingkat efisiensi serta gambaran mutu pelayanan di rumah sakit. Target ALOS RSUD S.K. Lerik Pada Tahun 2016 adalah sebanyak 3 hari, sedangkan realisasi atau capaiannya sebesar 1-2 hari. Hal ini dikarenakan adanya perawatan One Day Surgery (ODS) atau pasien One Day Care (ODC) termasuk kurang ketatnya rumah sakit terhadap 
indikasi pasien masuk rawat inap. Di samping itu juga dimungkinkan karena kasus yang ada di RSUD S.K. Lerik merupakan kasus-kasus yang relatif kurang berat sehingga sebagian besar memerlukan perawatan yang tidak terlalu lama. Jika dibandingkan dengan standar (Depkes, 2005) yaitu antara 6 - 9 hari, maka ALOS RSUD S.K. Lerik adalah belum ideal dan masih harus meningkatkan kinerja organisasi, pelayanannya dan sumber daya manusianya.

Perkembangan dan kemajuan suatu organisasi termasuk RSUD, tidak terlepas dari peranan sumber daya yang ada, baik itu sumber daya manusia, finansial, material dan mesin. Semua sumber daya ini harus benar-benar dimanfaatkan oleh organisasi agar dapat mencapai tujuan dari organisasi tersebut. Sumber daya manusia merupakan faktor penentu sukses tidaknya suatu organisasi. Sumber daya manusia juga merupakan faktor produksi yang dapat mempengaruhi faktor produksi lainnya, seperti mesin, material, modal dan lain-lain. Peranan sumber daya manusia dalam organisasi sangatlah penting karena unsur ini merupakan pengelola semua sistem yang ada dalam organisasi yang sulit digantikan dengan sumber daya lainnya. Selanjutnya, untuk mencapai kinerja organisasi secara maksimal, setiap organisasi harus berusaha memenuhi tujuannya dengan memanfaatkan sumber daya yang dimilikinya sambal menjamin keberlanjutan dalam jangka Panjang. Ini berarti bahwa tugas pekerjaan organisasi dilakukan secara efektif dan efisien serta tetap sesuai dengan kebutuhan semua pemangku kepentingan (stakeholders). Dengan demikian kinerja organisasi dapat tercapai sesuai dengan target yang telah ditetapkan (Suryani \& FoEh, 2018).

Peningkatan kinerja karyawan tidak hanya menjadi tanggung jawab pihak manajemen akan tetapi setiap karyawan juga perlu memiliki kesadaran dalam bekerja untuk mencapai kinerja yang optimal. Dapat dikatakan bahwa kinerja karyawan dalam setiap organisasi dipengaruhi oleh banyak faktor namun dalam penelitian ini difokuskan pada aspek kepemimpinan, disiplin dan pelatihan yang dijalani karyawan. Penelitian mengenai kinerja pegawai telah banyak dilakukan oleh beberapa peneliti sebelumnya, dengan hasil yang berbeda pula menurut tempat dan waktunya. Untuk itu, penelitian akan dilaksanakan untuk mengetahui dan menganalisis hal pertama yang berkaitan dengan gambaran profil kepemimpinan, disiplin, pelatihan dan kinerja pegawai RSUD SK Lerik. Tujuan selanjutnya adalah mengetahui dan menganalisis pengaruh masing-masing faktor kepemimpinan, disiplin dan pelatihan terhadap kinerja Pegawai RSUD SK Lerik Kota Kupang.

Kinerja adalah hasil yang diperoleh oleh suatu organisasi baik organisasi tersebut bersifat profit oriented dan non profit oriented yang dihasilkan selama satu periode waktu. Secara lebih tegas (Fahmi, 2010) menyatakan bahwa Kinerja merupakan hasil pekerjaan yang mempunyai hubungan kuat dengan tujuan strategis organisasi, kepuasan konsumen dan memberikan kontribusi ekonomi. Lebih lanjut dikatakan bahwa kinerja adalah gambaran mengenai tingkat pencapaian pelaksanaan suatu kegiatan atau program ataupun kebijakan dalam mewujudkan sasaran, tujuan, misi dan visi organisasi yang tertuang dalam perumusan skema strategis (strategic planning) suatu organisasi. 
Dalam Kamus Besar Bahasa Indonesia yang dikutip oleh Nawawi (2006: 63) dikatakan bahwa "kinerja adalah (a) sesuatu yang dicapai, (b) prestasi yang diperlihatkan dan (c) kemampuan kerja". Dalam bahasa Inggris istilah kinerja adalah performance. Performance merupakan kata benda. Jadi arti performance atau kinerja adalah hasil kerja yang dapat dicapai oleh seseorang atau kelompok orang dalam suatu organisasi, sesuai dengan wewenang dan tanggung jawab masing-masing dalam rangka upaya mencapai tujuan organisasi bersangkutan secara legal sesuai dengan moral maupun etika (Rahadi, 2010).

Kinerja karyawan sering diartikan sebagai pencapaian tugas, dimana karyawan dalam bekerja harus sesuai dengan program kerja organisasi untuk menunjukkan tingkat kinerja organisasi dalam mencapai visi, misi dan tujuan organisasi. Adapun indikator kinerja karyawan (Setiawan, 2015) adalah sebagai berikut; Quantity (kuantitas), Quality (kualitas), Timeliness (ketepatan waktu), Cost effectiveness (efektivitas biaya) dan Interpersonal impact (hubungan antar perseorangan).

Kinerja berasal dari kata job performance atau actual performance yang berarti prestasi kerja atau prestasi sesungguhnya yang dicapai oleh seseorang (FoEh \& Papote, 2021). Pengertian kinerja (prestasi kerja) adalah hasil kerja secara kualitas dan kuantitas yang dicapai oleh seorang pegawai dalam melaksanakan fungsinya sesuai dengan tanggung jawab yang diberikan kepadanya. Tidak dapat dipungkiri lagi bahwa kinerja suatu organisasi ditentukan oleh kualitas dari sumber daya manusia yang ada. Kinerja merupakan hasil kerja dan perilaku kerja yang telah dicapai dalam menyelesaikan tugas-tugas dan tanggung jawab yang diberikan dalam suatu periode tertentu (Kasmir, 2016).

Kinerja merupakan catatan tentang hasil-hasil yang diperoleh dari fungsi-fungsi pekerjaan tertentu atau kegiatan selama kurun waktu tertentu pula (Erlangga, 2017). Berdasarkan beberapa pendapat dimaksud, dapat disimpulkan bahwa kinerja adalah suatu kegiatan atau hasil kerja yang dicapai seseorang atau sekelompok orang dalam suatu organisasi untuk mencapai tujuan tertentu sesuai dengan hukum dan aturan-aturan yang telah ditentukan.

Kepemimpinan adalah kemampuan untuk mempengaruhi pihak lain, melalui komunikasi baik langsung maupun tidak langsung dengan maksud untuk menggerakkan orang-orang agar dengan penuh pengertian, kesadaran, dan senang hati bersedia mengikuti kehendak pimpinan itu. Sejalan dengan itu, Blancard dan Hersey (Sutrisno, 2016) juga menyatakan bahwa kepemimpinan adalah proses memengaruhi kegiatan individu dan kelompok dalam usaha untuk mencapai tujuan dalam situasi tertentu.

Dimensi kepemimpinan menurut Bass dan Avolio (dalam Setiana, 2015) adalah: (1) Idealized Influence, pemimpin harus menjadi contoh yang baik, yang dapat diikuti oleh karyawannya, sehingga akan menghasilkan rasa hormat dan percaya kepada pemimpin tersebut, (2) Inspirational Motivation, pemimpin harus bisa memberikan motivasi, dan target yang jelas untuk dicapai oleh karyawannya, (3) Intellectual Simulation, pemimpin harus mampu merangsang karyawannya untuk memunculkan ide-ide dan gagasan-gagasan baru, pemimpin 
juga harus membiarkan karyawannya menjadi problem solver dan memberikan inovasi-inovasi baru di bawah bimbingannya. Dan (4) Individualized Consideration, pemimpin harus memberikan perhatian, mendengarkan keluhan, dan mengerti kebutuhan karyawannya. Seluruh dimensi tersebut jika dilaksanakan dengan baik maka akan membantu dalam memaksimalkan peran pemimpin dalam perusahaan. Pemimpin diharapkan dapat meningkatkan kinerja karyawan dengan memberikan motivasi dan menstimulasi ide kreatif, memperhatikan karyawan dan kebutuhan khususnya, juga bisa menjadi pemimpin yang bersifat mengayomi serta seorang yang dapat dihormati oleh seluruh karyawannya.

Disiplin adalah tindakan manajemen untuk memberikan semangat kepada pelaksana standar organisasi. Ini adalah pelatihan yang mengarah pada upaya membenarkan dan melibatkan pengetahuan-pengetahuan, sikap dan perilaku pegawai sehingga ada kemauan pada diri pegawai untuk menuju pada kerjasama dan prestasi yang lebih baik (Sutrisno, 2016). Disiplin itu sendiri diartikan sebagai kesediaan seseorang yang timbul dengan kesadaran sendiri untuk mengikuti peraturan-peraturan yang berlaku dalam organisasi.

Peraturan-peraturan yang berkaitan dengan disiplin kerja antara lain: -Peraturan jam masuk, jam pulang, dan jam istirahat; - Peraturan dasar tentang berpakaian dan bertingkah laku dalam pekerjaan; - Peraturan cara-cara melakukan pekerjaan dan hubungan dengan unit kerja lain; - Peraturan tentang apa yang boleh dan apa yang tidak boleh oleh para pegawai selama dalam organisasi dan sebagainya (Sutrisno, 2016).

Disiplin kerja tentu saja tidak terjadi dengan sendirinya, karena perilaku manusia itu sendiri dibentuk karena adanya faktor-faktor yang mendasarinya. Sama halnya dengan disiplin kerja juga memiliki beberapa faktor yang berpengaruh terhadap pembentukan perilaku disiplin. Dimana disiplin kerja merupakan salah satu bentuk dari perilaku manusia. Menurut Hasibuan (2005), faktor-faktor yang dimaksudkan meliputi hal-hal sebagai berikut: (1) Tujuan dan kemampuan, tujuan dari pekerjaan yang dibebankan harus sesuai dengan kemampuan, agar pegawai dapat bekerja dengan baik, (2) Peranan pimpinan, adanya pimpinan yang dapat dijadikan contoh pegawai dalam berperilaku disiplin, (3) Keadilan, keadilan menerapkan disiplin pada pegawai tanpa membeda-bedakan pangkat dan golongan, (4) Balas jasa, adanya balas jasa (imbalan) akan memberikan kepuasan dan kecintaan pegawai terhadap pekerjaannya, (5) Pengawasan, tindakan mencegah atau mengetahui terjadinya kesalahan, meningkatkan prestasi kerja, mengaktifkan peran atasan dan bawahan, (6) Sanksi, adanya hukuman (punishment) bila ada pegawai yang melanggar aturan, (7) Ketegasan, adanya ketegasan atas pimpinan dalam menegur, (8) Hubungan kemanusiaan, lingkungan kerja yang menyenangkan akan memotivasi kedisiplinan kerja pegawai.

Selanjutnya, Hasibuan (2005) menyatakan bahwa indikator disiplin kerja yaitu : patuh pada jam kerja, patuh pada prosedur kerja, patuh pada perintah atasan, dan akurat dalam bekerja. Sementara itu, Sutrisno (2016) membagi disiplin dalam empat dimensi dengan sepuluh indikator, yaitu: (1) Dimensi taat terhadap aturan waktu (jam masuk kerja, jam istirahat, jam pulang kerja), (2) Dimensi taat terhadap peraturan (cara berpakaian, sopan santun, 
kepatuhan), (3) Dimensi taat terhadap aturan perilaku dalam pekerjaan (bertingkah laku, tanggung jawab, kesesuaian pekerjaan dengan kemampuan), (4) Dimensi taat terhadap peraturan lainnya yaitu norma yang berlaku.

Indikator disiplin yang digunakan dalam penelitian ini adalah indikator berdasarkan teori dari Hasibuan (2005), yaitu patuh pada jam kerja, patuh pada prosedur kerja, patuh pada perintah atasan, dan akurat dalam bekerja.

Simanjuntak (2011) mengemukakan bahwa pelatihan merupakan bagian dari investasi sumber daya manusia (SDM) untuk meningkatkan kemampuan dan keterampilan kerja, dan dengan demikian meningkatkan kinerja pegawai. Program pelatihan justru sangat diperlukan untuk melengkapi atau konpensasi atas rendahnya tingkat pendidikan dan rendahnya kualitas pendidikan para pekerja di Indonesia sekarang ini. Pelatihan merupakan wahana atau media untuk melakukan injeksi semangat atau mendongkrak kinerja sejalan dengan standar kinerja yang telah ditetapkan, sebab pelatihan dilakukan sebagai solusi terhadap problem kinerja individu dan kinerja organisasi (Sudarmanto, 2009).

Menurut Sofyandi (2013), bahwa ada 14 metode yang dapat diterapkan pada pelatihan, antara lain : (1) Job instruction training, dalam metode ini peserta program diberikan latihan langsung ditempat pekerjaan yang sebenarnya di bawah instruksi seorang trainer, supervisor, atau pegawai senior yang sudah berpengalaman. (2) Job rotation, pelatihan dilakukan dengan cara memindahkan pegawai dari suatu pekerjaan ke pekerjaan lain. Dengan metode ini diharapkan para peserta program dapat mengetahui dan mengerti tugas masing-masing. (3) Apprenticeship, saling belajar antara pegawai yang satu dengan pegawai lain yang berpengalaman. Pada umumnya metode ini mengombinasikan the job training dan off job classroom training. (4) Coaching, merupakan metode pelatihan di mana supervisor atau manajemen memberikan bimbingan dan contoh atau model kepada pegawai dalam pelaksanaan pekerjaan rutin mereka. (5) Lecture, metode ini lebih menekankan kepada pemberian teori secara lisan dan diorganisasikan secara formal. Metode ini digunakan apabila jumlah peserta program banyak sehingga biaya peserta relatif murah. (6) Video presentation, metode ini hampir sama dengan pemberian kuliah, tetapi dalam metode ini digunakan televisi, film, slide, dan sebagainya. (7) Vestibule training, dalam metode ini pelatihan dilaksanakan disuatu tempat yang khusus terpisah dari tempat yang sebenarnya dengan menggunakan peralatan yang sama dengan yang sebenarnya sehingga tidak mengganggu jalannya operasional perusahaan. (8) Role playing, di sini para peserta program diharuskan untuk memainkan atau menghayati peran, identifikasi yang berbeda agar para peserta dapat mengetahui perbedaan-perbedaan yang individu. (9) Behavior modeling, di sini suatu perilaku dipelajari atau dimodifikasi melalui observasi terhadap orang lain, maksudnya program belajar tidak melalui pengalaman orang lain. (10) Case study, dalam metode ini dipelajari kondisi nyata perusahaan selama jangka waktu tertentu dan bagaimana bertindak dalam kondisi demikian. Di samping itu para peserta program di minta untuk mengidentifikasi masalah-masalah, menganalisis situasi dan merumuskan penyelesaian-penyelesaian alternatif. (11) Simulation, 
metode ini berusaha menciptakan suatu tempat yang serupa dengan keadaan kondisi tempat kerja yang sesungguhnya. (12) Self-study, teknik ini menggunakan modul-modul tertulis, kasetkaset rekaman, kaset video yang dibagikan kepada para peserta pelatihan. (13) Programmed learning, merupakan bentuk lain dari metode belajar sendiri yang menggunakan booklet-booklet yang berisikan pertanyaan-pertanyaan beserta jawabannya dan program-program komputer. (14) Laboratory training, metode ini merupakan suatu bentuk kelompok yang terutama digunakan untuk mengembangkan interpersonal skills. Salah satu bentuk pelatihan adalah sensitivity training di mana para peserta program belajar menjadi lebih peka terhadap perasaan orang lain.

\section{Metode Penelitian}

Populasi dalam penelitian ini adalah seluruh pegawai pada RSUD S.K. Lerik Kota Kupang yang berjumlah 232 orang. Jumlah populasi penelitian ini berukuran relatif kecil namun telah memenuhi syarat untuk analisis SEM, sehingga digunakan sampling jenuh atau seluruh anggota populasinya diteliti. Jumlah sampel ini telah mencukupi untuk menggunakan analisis SEM, karena lebih dari 100 walaupun kurang dari 200 (Haryadi \& Julianita, 2015).

Berikut, dalam Tabel 2 memuat operasionalisasi variabel dan indikator-indikator variable penelitian.

Tabel 2. Operasionalisasi Variabel Penelitian

\begin{tabular}{|c|c|c|c|}
\hline Variabel & Definisi Operasional & Indikator & Skala \\
\hline $\begin{array}{c}\text { Kepemimpinan } \\
(\mathrm{X} 1)\end{array}$ & $\begin{array}{l}\text { Kepemimpinan dapat diartikan: } \\
\text { bagaimana seorang pimpinan bersikap, } \\
\text { mengatur serta mengarahkan bawahan } \\
\text { untuk bertindak, bersikap dan bekerja } \\
\text { sesuai arahan pimpinan. Variable } \\
\text { kepemimpinan diukur dari } 4 \text { indikator. }\end{array}$ & $\begin{array}{lr}\text { lklim saling } & \text { percaya, } \\
\text { Penghargaan } & \\
\text { terhadap } & \text { ide } \\
\text { bawahan, } & \text { Memper- } \\
\text { hitungkan perasaan } \\
\text { bawahan, } \\
\text { Perhatian dan } \\
\text { kenyamanan } \\
\text { bawahan }\end{array}$ & Ordinal (Likert) \\
\hline $\begin{array}{l}\text { Disiplin Kerja } \\
\text { (X2) }\end{array}$ & $\begin{array}{l}\text { Disiplin Kerja adalah tinggi rendahnya } \\
\text { ketaatan sikap dan tingkah laku } \\
\text { karyawan terhadap ketentuan- } \\
\text { ketentuan atau peraturan-peraturan } \\
\text { yang berlaku. }\end{array}$ & $\begin{array}{l}\text { Patuh pada jam kerja, } \\
\text { Patuh pada prosedur } \\
\text { kerja, Patuh pada } \\
\text { perintah atasan, } \\
\text { Akurat dalam bekerja }\end{array}$ & Ordinal (Likert) \\
\hline Pelatihan (X3) & $\begin{array}{l}\text { Pelatihan adalah kegiatan untuk } \\
\text { meningkatkan kinerja karyawan baik } \\
\text { dalam hal kompetensi kerja, } \\
\text { produktivitas, maupun keterampilan } \\
\text { yang diselenggarakan oleh Pemerintah } \\
\text { Provinsi NTT, RSUD S.K. Lerik, } \\
\text { Kementerian Kesehatan }\end{array}$ & $\begin{array}{ll}\text { Isi pelatihan, } & \text { Metode } \\
\text { pelatihan, } & \text { Sikap } \\
\text { instruktur, } & \text { Waktu } \\
\text { pelatihan } & \end{array}$ & Ordinal (Likert) \\
\hline Kinerja $(\mathrm{Y})$ & $\begin{array}{l}\text { Kinerja karyawan adalah keterampilan } \\
\text { yang dimiliki oleh karyawan dalam } \\
\text { melaksanakan tugas pekerjaannya } \\
\text { yang meliputi kemampuan teknik, } \\
\text { kemampuan konseptual, dan } \\
\text { kemampuan hubungan interpersonal. }\end{array}$ & $\begin{array}{l}\text { Kuantitas/jumlah } \\
\text { yang harus } \\
\text { diselesaikan, yg } \\
\text { Kualitas } \\
\text { dihasilkan, } \\
\text { Ketepatan waktu } \\
\text { kerja, Kemampuan } \\
\text { bekerja sama }\end{array}$ & Ordinal (Likert) \\
\hline
\end{tabular}


Jenis data yang digunakan dalam penelitian ini ada 2 yaitu data kualitatif berbentuk variable laten yang artinya variable-variabelnya tidak dapat diamati atau diukur secara langsung sehingga memerlukan beberapa indikator untuk mengukurnya (Suharsini, 2005). Selanjutnya, data kuantitatif, yaitu data yang diperoleh dari responden dalam bentuk angka-angka, yang kesemuanya dikumpulkan dengan menggunakan alat bantu kuesioner. Jawaban responden menggunakan skala Likert dengan 5 (lima) kategori pilihan jawaban, yakni: Sangat Tidak Setuju, Tidak Setuju, Cukup/Netral, Setuju dan Sangat Setuju.

Data hasil penelitian yang telah tertabulasi, selanjutnya dianalisis secara deskriptif dan analisis model persamaan structural (SEM) dengan langkah-langkah berikut. Analisis statistika deskriptif dilakukan dengan menghitung persepsi responden (Levis \& Rafael, 2013) dengan formula sebagai berikut:

$$
P s_{-p}=\left(\frac{\bar{X} P s_{-p}}{5}\right) \times 100 \%
$$

$$
\begin{array}{lll} 
& P s_{-p} & =\text { Kategori Persepsi } \\
\bar{X} P s_{-p} & =\text { Rata-rata skor untuk persepsi populasi } \\
5 & =\text { Skor tertinggi skala likert }
\end{array}
$$

Selanjutnya predikat atau kategori sikap dan rentang nilai uji deskriptif disajikan dalam Tabel 3 berikut:

Tabel 3. Predikat dan Rentang Nilai Uji Deskriptif

\begin{tabular}{ccc}
\hline No. & Pencapaian Skor Maksimum & Kategori Sikap/ Predikat \\
\hline 1. & $84-100$ & Sangat Baik \\
\hline 2. & $68-83$ & Baik \\
\hline 3. & $52-67$ & Cukup Baik \\
\hline 4. & $36-51$ & Tidak Baik \\
\hline 5. & $\leq 20-35$ & Sangat Tidak Baik \\
\hline
\end{tabular}

Sumber: Levis \& Rafael (2013)

Analisis SEM dipergunakan dalam penelitian ini karena semua variabel yang dipergunakan bersifat laten yaitu untuk pengukurannya memerlukan beberapa indikator. Selanjutnya, indikator-indikator dimaksud dinilai dengan Skala Likert yang bersifat ordinal (Efferin, Darmadji, \& Tjan, 2008). Sekalipun model penelitian tidaklah rumit sehingga bisa menggunakan analisis Regresi Linier Berganda namun model ini mensyaratkan penggunaan data dengan skala interval ataupun ratio. Selanjutnya, penelitian sosial umumnya menggunakan SEM yang dapat mengevaluasi kualitas pengukuran yaitu keandalan dan validitas alat ukur, khususnya hubungan kausal antara variabel-variabel yang tidak teramati atau variabel-variabel laten (Efferin et al., 2008).

Model kerangka pemikiran teoritis yang sudah dibangun, selanjutnya ditransformasikan ke dalam bentuk diagram jalur (path digram) untuk menggambarkan hubungan kausalitas antara variabel eksogen dengan variabel endogen. SEM akan mengkonversi gambar diagram alur tersebut menjadi persamaan menjadi estimasi. Dalam SEM dikenal faktor (construct) yaitu 
konsep-konsep dengan dasar teoritis yang kuat untuk menjelaskan berbagai bentuk hubungan. Di sini akan ditentukan alur sebab akibat dari konstruk yang akan dipakai dan atas dasar itu variabel-variabel untuk mengukur konstruk itu akan dicari. Adapun dalam menyusun bagan alur digambarkan dengan hubungan antara konstruk melalui anak panah. Anak panah yang digambarkan lurus menyatakan hubungan kausal yang langsung antara satu konstruk dengan konstruk lainnya. Garis lengkung yang terdapat antar konstruk dengan anak panah pada setiap ujungnya menunjukkan korelasi antar konstruk. Konstruk-konstruk yang dibangun dalam diagram alur dapat dibedakan dalam dua kelompok konstruk (Augusty, 2014), yaitu; kontruk eksogen dan endogen. Konstruk eksogen dikenal juga sebagai source variables atau independent variables yang tidak diprediksi oleh variabel lain dalam model. Konstruk eksogen adalah konstruk yang dituju oleh garis dengan satu ujung panah (Ghozali, 2011). Konstruk endogen, merupakan faktor-faktor yang diprediksi oleh satu atau beberapa konstruk. Konstruk endogen dapat memprediksi satu atau beberapa konstruk endogen lainnya, tetapi konstruk eksogen hanya dapat berhubungan kausal dengan konstruk endogen.

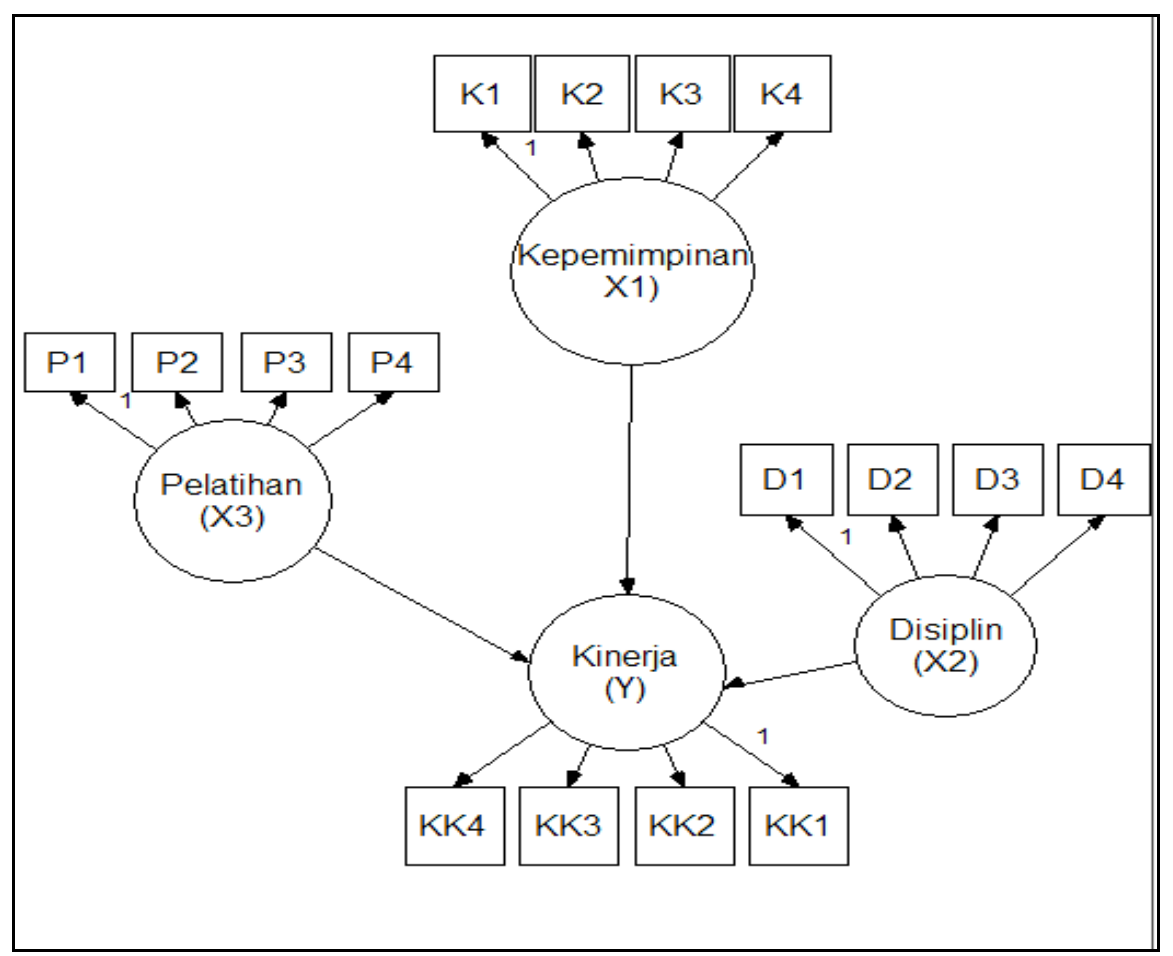

Sumber: Hasil Pengolahan Data (2021)

\section{Gambar 1. Diagram Alur}

Data yang digunakan, dievaluasi untuk dapat memenuhi asumsi-asumsi SEM sebagaimana diutarakan (Ferdinand, 2014), yaitu: (1) Ukuran sampel. Ukuran sampel minimum yang disarankan dalam penggunaan SEM adalah sebanyak 100. (2) Normalitas dan linearitas. Sebaran data harus dianalisis untuk melihat apakah asumsi normalitas dipenuhi. Normalitas dapat diuji melalui gambar histogram data. Uji linearitas dapat dilakukan melalui scatterplots dari data yaitu dengan memilih pasangan data dan dilihat pola penyebarannya untuk menduga ada tidaknya linearitas. (3) Outliers. Outliers, yang merupakan observasi dengan nilai-nilai 
ekstrim baik secara univariat maupun multivariat yang muncul karena kombinasi karakteristik unik yang dimilikinya dan terlihat sangat jauh berbeda dari observasi-observasi lainnya. (4) Multikolinearitas dan singularitas. Nilai determinan matriks kovarians yang sangat kecil memberikan indikasi adanya problem multikolineritas atau singularitas. Treatment yang dilakukan adalah dengan mengeluarkan variabel yang menyebabkan multikolineritas atau singularitas tersebut.

Beberapa jenis fit index yang mengukur derajat kesesuaian antara model yang dihipotesiskan dengan data yang disajikan, antara lain sebagai berikut (Augusty, 2014): (1) X2 (Chi-square) statistic. Alat uji yang paling fundamental untuk mengukur overall fit adalah likehood ratio Chi-square statistik. Chi-square ini bersifat sangat sensitif terhadap besarnya sampel yang digunakan. (2) GFI (Goodnes of Fit). Secara teoritis angka GFI berkisar antara 0 (poor fit) sampai 1 (perfect fit) dengan pedoman bahwa semakin baik model tersebut didalam menjelaskan data yang ada. Nilai GFI yang diharapkan adalah sebesar $\geq 0,90$. (3) AGFI (Ajusted Goodnes of Fit). AGFI adalah analog R2 dalam regresi berganda. Fit index ini dapat diadjust terhadap degress of freedom yang tersedia untuk menguji diterima tidaknya model. Tingkat penerimaan yang disarankan adalah apabila AGFI memiliki nilai $\geq 0,90$. (4) CMIN/DF (The Minimum Sample Discrepancy Function atau Degree of Freedom). CMIN/DF merupakan nilai Chi square dibagi dengan DF. Ukuran fit dalam nilai rasio ini $\leq 2,0$. (5) TLI (Tucker Lewis Index) adalah sebuah alternatif incremental fit index yang membandingkan sebuah model yang diuji terhadap sebuah baseline mode. Nilai yang direkomendasikan sebagai acuan untuk diterimanya sebuah model adalah $\geq 0,95$. (6) CFI (Comparative Fit Index). Index ini pada dasarnya membandingkan angka NCP (NonCentrality Parameter) pada berbagai model. CFI yang mendekati 1 mengindikasikan tingkat fit yang paling tinggi. Nilai yang direkomendasikan bagi CFI adalah $\geq 0,95$. (7) RMSEA (The Root Mean Square Error of Approximation) adalah sebuah indeks yang dapat digunakan untuk mengkompensasi Chi-Square Statistic dalam sampel yang besar. Nilai RMSEA yang $\leq 0,80$ merupakan indeks untuk dapat diterimanya model yang menunjukan sebuah close fit dari model itu berdasarkan derajat kebebasan (degrees of freedom).

\subsection{Kerangka Pikir Penelitian}

Keberhasilan organisasi dalam mencapai tujuannya tidak terlepas dari adanya dukungan dari faktor-faktor yang mendukung keberhasilan tersebut. Faktor-faktor tersebut di antaranya adalah budaya organisasi, kompetensi (Suharsini, 2005). Motivasi kerja dan kinerja anggota. Kuatnya budaya organisasi serta tingginya kompetensi dan motivasi kerja yang berdampak pada peningkatan kinerja anggota organisasi sehingga dapat dikatakan bahwa keempatnya saling mempunyai hubungan keterkaitan yang sangat erat dalam menentukan keberhasilan organisasi. 


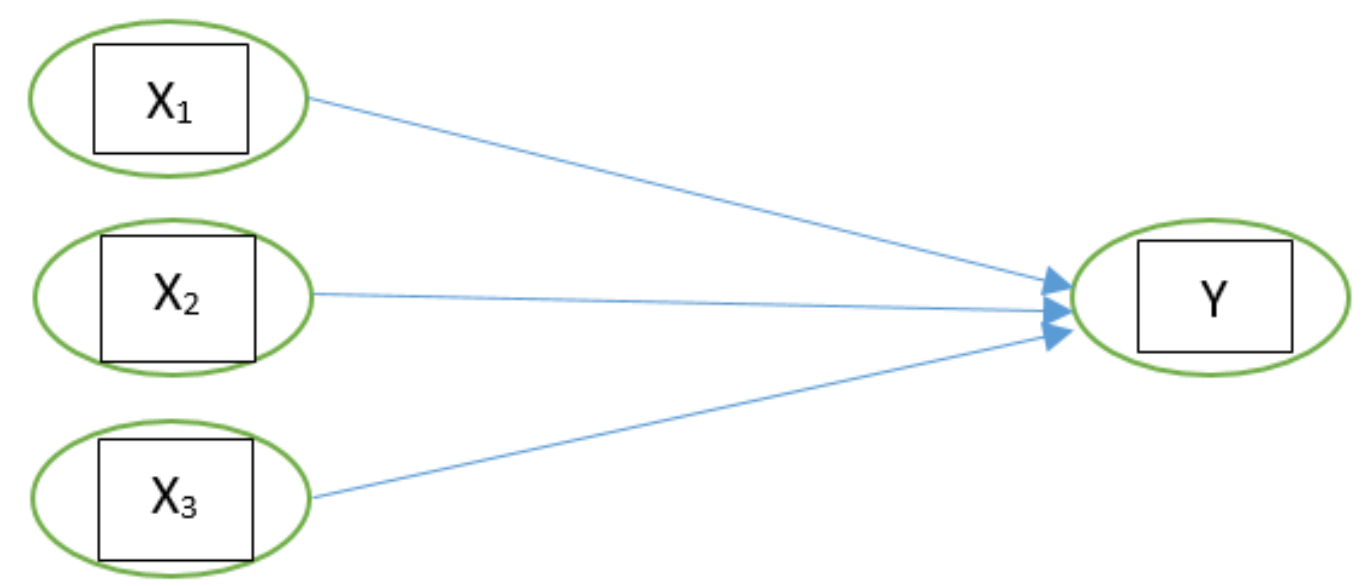

Sumber: Hasil Pengolahan Data (2021)

Gambar 2. Kerangka Pikir Penelitian

\subsection{Hipotesis}

Berdasarkan kerangka pemikiran tersebut, dapat diajukan hipotesis sebagai berikut: (1) Kepemimpinan (X1) berpengaruh signifikan terhadap kinerja pegawai (Y) pada RSUD S.K. (2) Disiplin (X2) berpengaruh signifikan terhadap kinerja pegawai (Y) pada RSUD S.K. Lerik Kota Kupang. (3) Pelatihan (X3) berpengaruh signifikan terhadap kinerja pegawai $(Y)$ pada RSUD S.K. Lerik Kota Kupang

\section{Hasil dan Pembahasan}

\subsection{Analisis Deskriptif}

Untuk mendapatkan gambaran umum tetang penilaian responden dalam kaitan dengan variabel-variabel yang diteliti maka digunakan adalah analisis statistik deskriptif dengan rumus capaian indikator sebagai berikut:

$\mathrm{CI}=\frac{\sum J \mathrm{R}}{\mathrm{SI}} \times 100 \%$

Keterangan: $\quad \mathrm{Cl} \quad$ : Capaian Indikator

$\sum \mathrm{JR} \quad$ : Jumlah Jawaban Responden

SI : Skor ldeal

Rata-rata angka persepsi responden (karyawan RSUD SK Lerik Kupang) untuk variabel kinerja adalah sebesar 78,43 atau berada dalam kategori / predikat baik. Untuk mencapai persepsi maksimal terhadap variable kinerja, perlu peningkatan terhadap indikator kualitas hasil kerja, ketepatan waktu kerja, kemampuan bekerjasama dan kuantitas hasil kerja. Rata-rata angka persepsi responden untuk variabel kepemimpinan adalah sebesar 79,27 atau berada dalam rentang predikat baik. Dapat disimpulkan bahwa indikator yang paling baik adalah indikator memperhitungkan perasaan staf dengan capaian indikatornya $80,78 \%$ dan yang paling rendah capaian indikatornya adalah indikator perhatian pada kenyamanan kerja staf dengan nilai 
78,13\%. Rata-rata angka persepsi responden untuk variabel disiplin adalah sebesar 80,47 atau juga berada dalam predikat baik. Indikator yang dinilai paling kecil pengaruhnya terhadap variable disiplin adalah indikator patuh pada jam kerja dengan capaian indikator sebesar $79,98 \%$. Sementara itu, rata-rata angka persepsi responden untuk variabel pelatihan adalah sebesar 77,80 atau predikat baik namun indikator metoda pelatihan hanya mencapai nilai indikator sebesar 74,16 . Walaupun seluruh hasil penilaian responden berada dalam kategori baik, namun rumah sakit yang baru dibangun 10 tahun lalu dan berkategori $\mathrm{C}$ ini masih perlu ditingkatkan dari berbagai aspek, mulai dari sarana dan prasarana rumah sakit, sumber daya manusia baik yang teknis maupun administratif masih perlu ditingkatkan.

\subsection{Analisis Statistik Inferensial}

\section{Uji Validitas dan Reliabilitas}

Hasil uji validitas yang dilakukan sebelumnya menunjukkan bahwa seluruh item pernyataan untuk variabel kinerja, budaya organisasi, kompetensi, pendidikan dan pelatihan serta motivasi kerja mempunyai nilai koefisien korelasi jauh lebih besar dari 0,3 sehingga dinyatakan valid. Untuk itu seluruh pernyataan yang diajukan dalam kuesioner penelitian ini dapat digunakan untuk mengukur variabel-variabel penelitian dimaksud. Selanjutnya, hasil uji reliabilitas menunjukkan bahwa seluruh item pernyataan memiliki nilai koefisien alpha Cronbach lebih besar dari 0,6 sebagaimana yang disyaratkan, sehingga semua item pernyataan dinyatakan reliabel dan dapat digunakan untuk mengukur variabel-variabel penelitian.

\section{Analisis Faktor Konfirmatori}

Analisis faktor konfirmatori adalah tahap penghitungan terhadap dimensi-dimensi yang membentuk variabel laten dalam model penelitian (Farouk \& Djaali, 2010). Berdasarkan hasil kalkulasi data terlihat bahwa semua indikator -dari seluruh variabel yang diteliti- sudah terpenuhi dan dapat dikatakan fit. Selain itu untuk menguji undimensionalitas indikator-indikator dari masing-masing variabel, dapat dilakukan dengan melihat bagian "estimates". Hasil analisis CFA untuk seluruh variabel (kinerja, kepemimpinan, disiplin dan pelatihan) menandakan korelasi yang baik, yaitu nilai $\mathrm{CR}$ untuk semua indikator di atas, 1.96 atau dengan probabilitas sebesar 0,000 atau lebih kecil dari 0,05. Hasil tersebut bisa menunjukkan bahwasanya terdapat indikator pembentuk semua variabel yang menandakan undimensionalitas. Berdasarkan analisis faktor konfirmatori konstruk ini, maka model penelitian dapat digunakan untuk analisis selanjutnya.

\section{Analisis Structural Equition Modelling (SEM)}

Analisis selanjutnya adalah analisis SEM secara full model, setelah dilakukan analisis terhadap tingkat undimensionalitas dari indikator pembentuk variabel laten yang diuji dengan analisis faktor konfirmatori. Analisis hasil pengolahan data pada tahap full model SEM dilakukan dengan menguji kesuaian dan uji statistik. Hasil pengolahan data untuk analisis full model SEM terdapat dalam Gambar 3. 


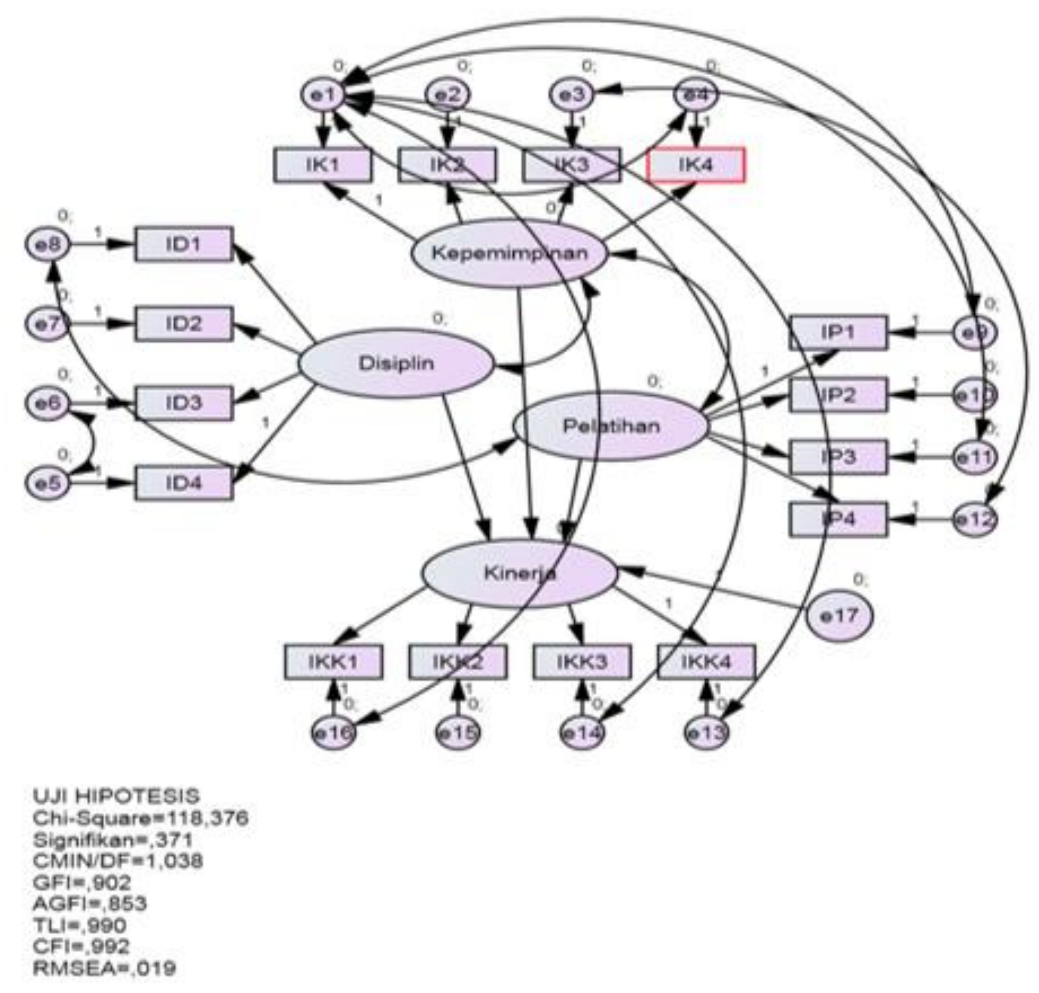

Sumber: Hasil Pengolahan Data (2021)

Gambar 3. Hasil Uji SEM

Pada tabel 4 menunjukkan hasil pengujian kelayakan model SEM.

Tabel 4. Hasil Pengujian Kelayakan Model SEM

\begin{tabular}{lccc}
\hline \multicolumn{1}{c}{ Goodness of Fit } & Cut-off Value & Hasil Analisis & Evaluasi Model \\
\hline Chi-Square & Kecil & 118.376 & Good Fit \\
\hline Probabilitas & $>0.05$ & 0.371 & Good Fit \\
\hline RMSEA & $\leq 0.08$ & 0.019 & Good Fit \\
\hline GFI & $\geq 0.90$ & 0.902 & Good Fit \\
\hline AGFI & $\geq 0.90$ & 0.853 & Marginal \\
\hline CMIN/ DF & $\leq 3$ & 1.038 & Good Fit \\
\hline TLI & $\geq 0.95$ & 0.990 & Good Fit \\
\hline CFI & $\geq 0.95$ & 0.992 & Good Fit
\end{tabular}

Sumber: Hasil Pengolahan Data Ulang (2020)

Uji terhadap kelayakan full model SEM diuji dengan menggunakan Chi square, GFI, CFI, TLI, CMIN/DF, dan RMSEA berada dalam rentang nilai yang menunjukkan semua nilai dari indikator telah memenuhi syarat atau kategori Good Fit, kecuali, meskipun nilai AGFI masih marginal tetapi mendekati 1 (satu) sehingga dapat diterima.

\section{Pengujian Asumsi SEM}

Nilai Outliers. Outlier adalah observasi atau data yang memiliki karakteristik unik yang terlihat sangat berbeda dengan data lainnya dan muncul dalam bentuk nilai ekstrim, baik untuk variabel tunggal maupun kombinasi. Asumsi SEM selanjutnya adalah outlier, asumsinya adalah terdapat outlier jika nilai mahalonobis d-squared > Chi-Square. Berdasarkan hasil olahan data, dapat disimpulkan bahwa semua nilai mahalonobis d-squared $(91,896)<$ chi-squared $(118,376)$ sehingga disimpulkan bahwa tidak terdapat multivariate outliers. 
Normalitas Data. Pengujian selanjutnya adalah melihat tingkat normalitas data yang digunakan dalam penelitian ini. Pengujian ini adalah dengan mengamati nilai skewness data yang digunakan, apabila nilai $C R$ pada skewness data berada pada rentang antara \pm 2.58 ($2.58<\mathrm{CR}<2.58$ ) atau berada pada tingkat signifikan 0.01 . Uji normalitas secara univariate dapat dilakukan dengan melihat nilai $\mathrm{CR}$ dari skew dan kurtosis, dimana nilai kedua ratio yang memiliki nilai yang lebih besar dari nilai mutlak 2.58, berarti data tersebut berdistribusi normal. Dari data di atas, diketahui bahwa tidak terdapat nilai CR untuk skewness yang berada diluar rentang \pm 2.58 . Dengan demikian maka data penelitian yang digunakan telah memenuhi persyaratan normalitas data, atau dapat dikatakan bahwa data penelitian telah terdistribusi normal.

Asumsi atas Multicollinearity dan Singularity. Pengujian selanjutnya adalah melihat apakah terdapat multikolinearitas dan singularitas dalam sebuah kombinasi variabel. Indikasi adanya multikolinearitas dan singularitas dapat diketahui melalui nilai determinan matriks kovarians yang benar-benar kecil, atau mendekati nol. Dari hasil pengolahan data dapat dilihat nilai determinan matriks kovarians sampel adalah determinant of sample covariance matrix $=0.050$. Evaluasi Nilai Residual. Setelah model di estimasi residualnya haruslah kecil atau mendekati nol dan distribusi frekuensi dari kovarian residual harus bersifat simetrik. Jika suatu model memiliki nilai kovarians residual yang tinggi, maka sebuah modifikasi perlu dipertimbangkan dengan catatan landasan teoritisnya. Bila ditemukan bahwa nilai residual yang dihasilkan oleh model itu cukup besar ( $\geq 2.58$ ), maka cara lain dalam memodifikasi adalah dengan mempertimbangkan untuk menambah sebuah alur baru terhadap model yang di estimasi. Data standarized residual covariances yang diolah dengan program AMOS memberikan hasil bahwa nilai residual 0,550 atau tidak lebih besar dari 2.58, sehingga dapat dikatakan bahwa residual mendekati pola dan distribusi frekuensi dari kovarian yang bersifat simetrik.

\subsection{Pengujian Hipotesis}

Setelah semua asumsi terpenuhi, selanjutnya akan dilakukan pengujian hipotesis sebagaimana diajukan pada bab sebelumnya. Pengujian 4 hipotesis penelitian ini dilakukan berdasarkan nilai Critical Ratio (CR) suatu hubungan kausalitas dari hasil pengolahan data SEM seperti tertera dalam Tabel 5

Tabel 5. Pembobotan Regresi SEM

\begin{tabular}{lcccccc}
\hline \multicolumn{1}{c}{ Keterangan } & Estimate & S.E. & C.R. & P & Label & $\begin{array}{c}\text { Standarized } \\
\text { Regression Weight }\end{array}$ \\
\hline Kinerja <- Kepemimpinan &, 071 &, 021 & 3,361 & ${ }^{* * *}$ & Par_15 &, 064 \\
\hline Kinerja <- Disiplin &, 064 &, 064 & 1,010 &, 312 & Par_14 &, 019 \\
\hline Kinerja <- Pelatihan & 1,568 &, 145 & 10,786 & ${ }^{* * *}$ & Par_13 & 1,458 \\
\hline Sumber: Data Primer diolah Kembali $(2020)$ & & & & & &
\end{tabular}

Sumber: Data Primer diolah Kembali (2020)

\section{Pengujian Hipotesis I}

Hasil analisis menunjukkan bahwa pengaruh kepemimpinan terhadap kinerja pegawai RSUD S.K. Lerik adakah signifikan. Hal ini ditunjukkan dari parameter estimasi untuk pengujian pengaruh kepemimpinan terhadap kinerja pegawai RSUD S.K. Lerik menunjukkan nilai CR sebesar $3.361 \geq 1.96$ dan dengan probabilitas yang lebih kecil dari 0,05. Kedua nilai tersebut 
memenuhi syarat untuk penerimaan Hipotesis 1. Hal ini berarti bahwa semakin baik kepemimpinan maka akan semakin baik kinerja pegawai RSUD S.K Lerik Kota Kupang.

\section{Pengujian Hipotesis II}

Berdasarkan data pada Tabel 5, parameter estimasi untuk pengujian pengaruh disiplin terhadap kinerja pegawai RSUD S.K Lerik menunjukkan nilai CR sebesar 1,010 dan dengan probabilitas sebesar 0.312. Kedua nilai tersebut tidak memenuhi syarat untuk penerimaan Hipotesis 2 karena nilai $\mathrm{CR}$ yang diperoleh lebih besar dari 1.96 dan probabilitas yang lebih besar dari 0.05. Dengan demikian, dapat disimpulkan bahwa variabel Disiplin tidak berpengaruh secara signifikan terhadap kinerja pegawai RSUD S.K. Lerik Kota Kupang, maka hipotesis 2 yang menyatakan bahwa disiplin berpengaruh signifikan terhadap kinerja pegawai pada RSUD S.K. Lerik Kota Kupang, ditolak.

\section{Pengujian Hipotesis III}

Parameter estimasi untuk pengujian pengaruh pelatihan terhadap kinerja pegawai RSUD S.K Lerik menunjukkan nilai $C R$ sebesar 10.786 dan dengan probabilitas sebesar 0.001 . Hasil ini memenuhi syarat untuk penerimaan hipotesis 3 , yaitu nilai $C R$ sebesar $10.786 \geq 1.96$ dan probabilitas yang lebih kecil dari 0.05 . Dengan demikian dapat disimpulkan bahwa variabel Pelatihan secara signifikan berpengaruh terhadap kinerja pegawai RSUD S.K. Lerik Kota Kupang.

\subsection{Pembahasan}

\section{Pengaruh Kepemimpinan Terhadap Kinerja Pegawai}

Dari hasil statistic inferensial, diketahui bahwa setiap indikator-indikator atau dimensi pembentuk masing-masing variabel kepemimpinan menunjukkan hasil baik, yaitu nilai Critical Ratio (C.R) di atas, 1.96 atau dengan probabilitas yang lebih kecil dari 0.05 , maka kovariankovarian faktor mempunyai hubungan signifikan. Pengujian hipotesis membuktikan bahwa variable kepemimpinan berpengaruh signifikan terhadap kinerja pegawai. Pengaruh ini ditunjukkan dengan nilai $\mathrm{CR}$ sebesar $3.361 \geq 1.96$ dan dengan probabilitas yang lebih kecil dari 0,05 . Interpretasinya adalah apabila kepemimpinan semakin baik maka kinerja pegawai akan semakin baik dan sebaliknya jika kepemimpinan menurun maka kinerja pegawai juga akan menurun.

Hasil penelitian ini sejalan dengan penelitian yang dilakukan oleh Hardiyana \& Helwiyan (2011), menyatakan kepemimpinan berpengaruh signifikan terhadap kinerja pegawai pada Badan Kepegawaian Pendidikan dan Pelatihan Kabupaten Bandung. Temuan penelitian yang sejalan juga adalah hasil penelitian yang dilakukan oleh Destia (2011), Juhana dan Haryati (2013), dan Mawuntu (2016) yang menunjukan bahwa kepemimpinan berpengaruh signifikan terhadap kinerja pegawai. Selain itu hasil penelitian ini juga sesuai dengan pendapat Wijayanti (2012), kepemimpinan saling terkait dalam mempengaruhi kinerja pegawai di dalam suatu organisasi atau Lembaga. Hal ini dikarenakan kepemimpinan merupakan proses mempengaruhi, menggerakkan, mengarahkan, mendorong dan mengajak orang lain untuk bekerja sama dan mau bekerja secara produktif guna pencapaian tujuan tertentu. 


\section{Pengaruh Disiplin Terhadap Kinerja Pegawai}

Hasil analisis melalui uji pembobotan regresi menunjukkan nilai CR sebesar 1,010 dan dengan probabilitas sebesar 0.312 . Kedua nilai tersebut tidak memenuhi syarat karena nilai $\mathrm{CR}$ lebih kecil dari 1.96 dan probabilitas yang lebih besar dari 0.05 . Hal ini berarti bahwa disiplin (X2) tidak berpengaruh secara signifikan terhadap kinerja pegawai $(Y)$.

Temuan penelitian ini sejalan dengan hasil penelitian yang dilakukan oleh Tasik (2016) yang berjudul Prestasi Kerja Pegawai Negeri Sipil Badan Kepegawaian Daerah Kota Kupang yang menunjukan bahwa disiplin kerja tidak berpengaruh secara signifikan terhadap kinerja pegawai. Namun, hasil penelitian ini tidak sejalan dengan hasil penelitian dari Hardiyana dan Helwiyan (2011) dengan judul penelitian Pengaruh kepemimpinan, disiplin kerja, dan lingkungan kerja terhadap Kinerja Pegawai Badan Kepegawaian Pendidikan dan Pelatihan Kabupaten Bandung. Hasil penelitiannya menyatakan bahwa Kepemimpinan, disiplin kerja, dan lingkungan kerja, berpengaruh signifikan terhadap kinerja pegawai. Kemungkinan yang menyebabkan adanya perbedaan hasil penelitian ini adalah perbedaan objek penelitian, jumlah sampel, serta perbedaan karakteristik responden. Objek penelitian yang dilakukan oleh Hardiyana dan Helyiwan adalah pada Badan Kepegawaian Pendidikan dan Pelatihan Kabupaten Bandung dengan jumlah sampel 100 responden. Selain itu, responden juga berbeda karakteristik, dimana responden pada penelitian Hardiyana dan Helyiwan adalah PNS yang bertugas melayani kebutuhan pegawai dalam bidang kepegawaian, pendidikan dan pelatihan sedangkan responden pada penelitian RSUD S.K. Lerik Kota Kupang adalah pegawai dengan mayoritas tenaga kesehatan.

\section{Pengaruh Pelatihan Terhadap Kinerja Pegawai}

Hasil analisis pembobotan regresi menunjukkan nilai CR sebesar 10.786 dan dengan probabilitas sebesar 0.001 , maka apabila terjadi perubahan kenaikan dan penurunan pada variabel Pelatihan akan mengakibatkan terjadi kenaikan dan penurunan kinerja pegawai RSUD S.K Lerik Kota Kupang. Dalam artian bahwa semakin banyak keterlibatan pegawai dalam kegiatan pelatihan yang diadakan oleh RSUD S.K Lerik atau istansi yang terkait lainnya maka tingkat kemampuan dan pengetahuan akan semakin tinggi yang dapat mempengaruhi kinerja semakin baik. Dari pernyataan dimaksud menunjukan bahwa variabel pelatihan yang digunakan dalam menelitian ini menunjukan hasil yang baik dan sejalan dengan pendapat Suwatno dan Yuniarsih (2009) bahwa pelatihan merupakan proses memberikan atau meningkatkan kemampuan dan keterampilan serta menanamkan sikap kepada pegawai untuk mendapatkan kualitas sumber daya manusia yang baik serta membantu pegawai untuk mengoreksi dan memperbaiki kekurangan-kekurangan dalam pekerjaannya yang dapat mengakibatkan peningkatan kinerjanya lebih baik.

\section{Kesimpulan}

Berdasarkan hasil analisis yang telah dibahas, maka kesimpulan dari hasil penelitian ini adalah sebagai berikut: Hasil analisis deskriptif menunjukkan bahwa profil kepemimpinan, 
disiplin, pelatihan dan kinerja pegawai RSUD S.K. Lerik Kota Kupang adalah baik. Variabel kepemimpinan berpengaruh signifikan terhadap kinerja pegawai RSUD S.K. Lerik Kota Kupang. Variabel disiplin tidak berpengaruh signifikan terhadap kinerja pegawai RSUD S.K. Lerik Kota Kupang. Variable pelatihan berpengaruh signifikan terhadap kinerja pegawai RSUD S.K. Lerik Kota Kupang dan variabel pelatihan yang paling besar pengaruhnya. Dari kesimpulan yang ada, maka saran yang direkomendasikan adalah: RSUD S.K. Lerik Kota Kupang perlu memperhatikan variabel kepemimpinan, terutama pada indikator Perhatian pada Kenyamanan Kerja Staf yang memperoleh nilai terendah dalam variabel kepemimpinan. Caranya adalah dengan meningkatkan kenyamanan dalam ruangan seperti menyediakan AC dan memperhatikan kebersihan ruangan-ruangan dan lingkungan sekitar, terutama terkait pembuangan limbah medis dan lain-lain. Penelitian hanya terbatas pada variabel-variabel kepemimpinan, disiplin dan pelatihan serta tidak menjelaskan mengenai pengaruh setiap dimensi pada kinerja karyawan di RSUD SK Lerik Kota Kupang. Tambahan, diperlukan tambahan pengujian terhadap variabel-variabel lain seperti, gaya kepemimpinan, kompensasi, suasana kerja, fasilitas kerja dan lain-lain dengan kepuasan kerja sebagai variabel intervening. Variabel-variabel ini belum diteliti di sini karena menyangkut hal yang cukup sensitif dan memerlukan persetujuan institusi. Penelitian ini menggunakan metode survey melalui kuesioner yang dikirimkan ke seluruh karyawan RSUD SK Lerik Kota Kupang. Dengan demikian jika penelitian ini diterapkan ke jumlah populasi atau sampel yang lebih besar maka pasti variasi hasilnya akan lebih bisa menggambarkan kondisi karyawan yang sesungguhnya.

\section{Daftar Pustaka}

Augusty, F. (2014). Metode Penelitian Manajemen. Semarang: Universitas Diponegoro.

Destia. (2011). Manajemen Sumber Daya Manusia (Revisi). Jakarta: PT Bumi Aksara.

Efferin, S., Darmadji, \& Tjan, Y. (2008). Metode Penelitian Akuntansi; Mengungkap Fenomena dengan Pendekatan Kualitatif dan Kuantitatif (1st ed.). Yogyakarta: Graha IImu.

Erlangga, C. Y. (2017). Pengaruh Gaya Kepemimpinan, Motivasi Dan Disiplin Kerja Terhadap Kinerja Karyawan. Komunikasi, 5(1). https://doi.org/https://doi.org/10.32493/skr.v5i1.1103

Fahmi, I. (2010). Manejemen Kinerja Teori dan Aplikasi. Bandung: CV. Alfabeta.

Farouk, M., \& Djaali. (2010). Metodologi Penelitian Sosial. Jakarta: Restu Agung.

Ferdinand, A. T. (2014). Structural Equation Modeling Dalam Penelitian Manajemen. Semarang: Universitas Diponegoro.

FoEh, J. E., \& Papote, E. (2021). Analisis Faktor-faktor Yang Mempengaruhi Kinerja Anggota Ditlantas Kepolisian Daerah NTT. ULTIMA Management. Jurnal IImu Manajemen, 13(1), 148-163. https://doi.org/https://doi.org/10.31937/manajemen.v13i1.2046

Ghozali, I. (2011). Aplikasi Analisis Multivariate dengan Program IBM SPSS 19. Universitas Diponegoro.

Hardiyana, A., \& Helwiyan, F. (2011). Pengaruh Kepemimpinan, Motivasi, dan Lingkungan Kerja terhadap Kinerja Pegawai Badan Kepegawaian Pendidikan dan Pelatihan 
Kabupaten Bandung. Ekonomi, Bisnis Dan Entresneurship, 5(2), 86.

Haryadi, S., \& Julianita, W. (2015). Structural Equation Modeling (SEM); Sebuah Pengantar Aplikasi untuk Penelitian Bisnis. Jakarta: Salemba Empat.

Hasibuan, H. M. (2005). Manajemen Sumber Daya Manusia. Jakarta: PT Bumi Aksara.

Juhana, D., \& Haryati. (2013). Pengaruh Motivasi, Kepemimpinan, Disiplin Dan Lingkungan Kerja Terhadap Kinerja Pegawai pada Dinas Kesehatan Kota Cimahi. Jurnal Ekonomi Bisnis Dan Enterpreneurship, 7(2), 84. Retrieved from https://jurnal.stiepas.ac.id/index.php/jebe/article/view/173

Kasmir. (2016). Manajemen Sumber Daya Manusia (Teori dan Praktik) (1st ed.). Jakarta: Raja Grafindo Persada.

Levis, \& Rafael, L. (2013). Metode Penelitian Perilaku Petani. Maumere: Ledalero.

Mawuntu, Y. K. (2016). Pengaruh Kompetensi, Motivasi, Dukungan Organisasi dan Kepemimpinan terhadap Kinerja Pegawai pada Sekretariat DPRD Provinsi Nusa Tenggara Timur. Universitas Katolik Widya Mandiri.

Nawawi, H. (2006). Evaluasi dan Manajemen Kinerja di Lingkungan Perusahaan dan Industri. Yogyakarta: UGM Press.

Rahadi, D. R. (2010). Manajemen Kinerja Sumber Daya Manusia. Malang: Tunggal Mandiri Publishing.

Setiana, Y. Hubungan Antara Gaya Kepemimpinan Dengan Kinerja Karyawan Melalui Motivasi Pada Koperasi Serba Usaha Tandangsari Sumedang. , (2015).

Setiawan, K. C. (2015). Pengaruh motivasi kerja terhadap kinerja karyawan level pelaksana di divisi operasi PT. Pusri Palembang. Psikis : Jurnal Psikologi Islami, 1(2), 43-53. Retrieved from http://jurnal.radenfatah.ac.id/index.php/psikis/article/view/567

Simanjuntak, P. J. (2011). Manajemen dan Evaluasi Kinerja. Jakarta: Fakultas Ekonomi UI. Sofyandi. (2013). Manajemen Sumber Daya Manusia. Bandung: CV. Alfabeta.

Sudarmanto. (2009). Kinerja dan Pengembangan Kompetensi Sumber Daya Manusia (1st ed.). Yogyakarta: Pustaka Belajar.

Suharsini, A. (2005). Manajemen Penelitian. Jakarta: Rineka Cipta.

Suryani, N. K., \& FoEh, J. E. (2018). Kinerja Organisasi. Yogyakarta: Deepublish.

Sutrisno, E. (2016). Manajemen Sumber Daya Manusia (8th ed.). Jakarta: Prenada Media Group.

Suwatno, \& Yuniarsih, T. (2009). Manajemen Sumber Daya Manusia. Bandung: CV. Alfabeta.

Tasik, A. M. . (2016). Prestasi Kerja Pegawai Negeri Sipil Badan Kepegawaian Daerah Kota Kupang. Universitas Katolik Widya Mandiri.

Wijayanti, D. W. (2012). Pengaruh Kepemimpinan dan Motivasi Kerja terhadap Kinerja Pegawai pada PT. Daya anugerah Semesta Semarang. Universitas Negeri Semarang. 